\title{
A REVIEW ON THE CURRENT DRUGS AND NEW TARGETS FOR OBESITY
}

\author{
Poojashree $\mathrm{M} \mathrm{J}^{1}$ *, Siddalingaprasad H S ${ }^{2}$, Swetha B R ${ }^{1}$, Shivukumar Swamy ${ }^{1}$
}

\author{
Article Information \\ Received: $13^{\text {th }}$ May 2019 \\ Revised: $17^{\text {th }}$ October 2019 \\ Accepted: $24^{\text {th }}$ December 2019
}

Keywords

Obesity, Diet, BMI, weight gain

\begin{abstract}
Obesity is defined as the condition in which the Body Mass Index (BMI) of an individual is between 25 and 29.5 that is $\geq 30 \mathrm{~kg} / \mathrm{m}^{2}$ and is caused by the imbalance management of energy intake and expenditure. Obesity is among the most prevalent diseases in the world and approximately over $10 \%$ of the people belong to overweight group in the world and over $5 \%$ in India. Currently many drugs are used to treat or to manage obesity. But these drugs also account for several side effects. So there is an extensive need of promising drugs which can control obesity with greater efficacy and economic viability. This review focusses on the current drugs in the market used to treat obesity and also few of the new probable targets to discover drugs.
\end{abstract}

\section{INTRODUCTION}

Obesity, the most common and complex disorders of this generation caused due to reasons like genetic heredity, diet and environmental factors [1]. Obesity can be defined as a state of an individual where the Body mass index (BMI) is more $\geq 30 \mathrm{~kg} / \mathrm{m}^{2}$ and is caused by the imbalance management of energy intake and expenditure. Obesity is more common in the youngsters when compared to the elder people mainly due to the lifestyle. Obesity has a major influence on social and psychological status of a person which eventually causes depression. Physiologically it will also cause many of the diseases including cardiac problems [2]. In the world approximately $10 \%$ of the population belongs to overweight group. Over 40 million children under age of 5 and 340 million above the age of 5 are obese in the year 2016 [4, 5]. USA,
China, India will occupy more than $50 \%$ of the obesity in the world. Currently, there are many drugs are used for the treatment of obesity but these drugs have numerous side effects. Therefore, there is an extensive need of such a kind of drugs which can control obesity with greater efficacy and economic viability [3].

Major pathogenesis occurs due to either over appetite or dysregulation of energy utilizing functions in the body. This kind of situation results in accumulation of fat that in turn makes more adipose tissue. This alerts the secretion of cytokine in higher amount and thereby causes vascular complications due to hyperlipidemia. This may in turn cause cardiovascular diseases and in most cases liver, gall stone and gut related diseases. Therefore management of the obesity is very much essential to restrain these diseases [5]. It is very important to

\footnotetext{
${ }^{1}$ Mallige College of Pharmacy, \#71, Silvepura, Chikkabanavara Post, Bengaluru 560090

${ }^{2}$ Department of Studies and Research in Biochemistry, Tumkur University, Tumakuru, Karnataka 572103
}

*For Correspondence: poo.sana25@gmail.com

\section{C2020 The authors}

This is an Open Access article distributed under the terms of the Creative Commons Attribution (CC BY NC), which permits unrestricted use, distribution, and reproduction in any medium, as long as the original authors and source are cited. No permission is required from the authors or the publishers. (https://creativecommons.org/licenses/by-nc/4.0/) 
maintain the fatty acids, triglycerides and cholesterol in the blood at very low level because higher amount of these molecules will start accumulating in the adipose all over the body called atherosclerosis and if it is not controlled may lead to myocardial infarction and stroke. This also results in the increase of oxidative stress, lipotoxicity, hypertriglyceridemia and other complications like diabetes. Managing and reducing the oxidative stress to prevent the obesity and few other complications [5].

Obesity anyhow can be managed either by reducing the appetite or by enhancing the calorie utilization. Hunger and satiety are managed by regulating the hormones which are responsible for hunger. However physical exercise can prevent the accumulation of white adipose [6]. The goal of treatment is to make the individual to attain and stay at healthy weight. The preliminary treatment target is a sudden loss of weight of $5 \%$ to $10 \%$ of the total weight. However, loss of more weight has greater benefits [7]. If the individual wants to reduce weight, the person must change eating habits and do lot of physical exercise [8]. The treatment methods which are right for the individual directly depend on the obesity severity, health and the enthusiasm in willingness in losing weight. Doctors may recommend medication for the weight loss only if the other plans like diet and exercise do not work [9]. Doctors will consider the health history of the person and possible side effects before choosing any medication for the obese patient [10]. Few of the medications can't be given to pregnant women and to the people with chronic health diseases [11]. Plethora of information available in the literature suggests that variety of drugs used treat obesity [12-26].

Medication for obesity is so interesting and confusing that one medicine can't react the same way to others and in few cases the effects may be slower as the time passes. Pausing or stopping of the medication will result in the regain of the full or little weight which was lost. Keeping these things in mind, a common, economically viable and effective drug is required to control obesity and with a proper diet plan which can substantially decrease the obesity of the individual.

\section{Physiological study of Obesity}

Development of obesity involves various pathological events at molecular level. Excess intake of food and less physical exercise leads to the condition of obesity [27]. A few number of the cases are due to genetic inheritance, medical problems or psychiatric problems [28]. Obesity occurs due to the interplay between genetic and also environmental factors. All the People who exposed urban and rural environments will become obese, it means that there is some genetic mechanism working at the individual level. Hypothalamus expresses Leptin and Melanocortin-4 receptors, which are involved in the regulation of homeostasis in the neural circuits. Inefficiency to express those proteins also brings obesity in the individuals [29]. People with multiple copies of FTO gene (Fat mass \& obesity associated gene) are found to have 1.67 times higher risk of the obesity than the people who do not possess that extra copy of gene.

Addition to insulin, glucagon, somatostatin, somatropin, cortisol, gastric inhibitory polypeptide/glucose-dependent insulinotropic peptide [GIP], adinopectin thyroxin, chemerin, perilipin-1, apelin, GLP-1 catecholamines and cholecystokininpancreozymin there are other 5 molecules which are produced endogenously have been found to regulate the apetite, satiety, storage of energy and metabolism. It includes Leptin, Obestatin, Endocannabinoids, Ghrelin and Nesfatin-1 [29].

\section{Current Drug based therapy for Obesity}

People with diabetes, sleep apnea, hypertension, arthritis and hyperlipidemia have many risk factors for the treatment of obesity using pharmacological therapy [30]. At present none of the drugs have been taken for clinical trials for more than 4 years and also most of the drugs have serious side effects. Treating obese person with drugs for a short period may have side effects but it benefits for treating obesity. For any drug to consider it as antiobesity drug, it should reduce the weight at least by $2 \mathrm{~kg}$ within 30 days and 5-8\% in the next 180 days. Pharmacotherapy will be considered effective only if the patient loses at least $10-15 \%$ of the initial weight in 1-2 years period [31]. After starting treatment, decrease in the weight should be $10-15 \%$ of the initial weight within one year, then only the demonstrated therapeutic drug will be called as antiobesity drug. After losing weight, patients have to reduce the intake of energy by $8 \mathrm{kcal} / \mathrm{kg}$ [32].

There are many agents used to treat obesity, they have different target and different mechanism of action. Appetite suppressant drugs, antidiabetic agents, anticonvulsant drugs, inhibitors of pancreatic lipase, serotonin 5-HT2c agonists, antidepressants, beta 3 adrenoceptor agonists, hormones and hormone analogues and other combinational formulae are the kind of drugs used in treating obesity. Clinician should select the type 
of drug for each individual using the clinical trial data available and prescribe the drug along with some diet restriction and physical exercise. Some of the approved antiobesity drugs are listed in the Table 1.

Table 1: Drugs which are approved by various authorities for treating obesity

\begin{tabular}{|c|c|c|c|c|c|c|}
\hline Drug & $\begin{array}{l}\text { Brand } \\
\text { name }\end{array}$ & $\begin{array}{l}\text { Treatment } \\
\text { period }\end{array}$ & $\begin{array}{l}\% \text { or } \mathrm{kg} \text { of } \\
\text { weight loss }\end{array}$ & Mechanism of action & $\begin{array}{l}\text { Drug } \\
\text { Approved } \\
\text { authority }\end{array}$ & Reference \\
\hline Orlistat & Xenical & 4 years & Approx. 3\% & TAG lipase inhibitor & $\begin{array}{l}\text { EMA, FDA, } \\
\text { ANVISA }\end{array}$ & {$[33,34]$} \\
\hline Bupropion & $\begin{array}{l}\text { Buproban, } \\
\text { Wellbutrin, } \\
\text { Zyban }\end{array}$ & 24 weeks & Approx. $13 \%$ & $\begin{array}{l}\text { Inhibits Noradrenaline and dopamine } \\
\text { reuptake }\end{array}$ & FDA & {$[35]$} \\
\hline $\begin{array}{l}\text { Naltrexone/ } \\
\text { bupropion }\end{array}$ & Contrave & 24 weeks & $\begin{array}{l}\text { Between } 6.1 \\
\text { to } 9.3 \%\end{array}$ & $\begin{array}{l}\text { Inhibits Opioid receptor antagonist/ } \\
\text { Noradrenaline and dopamine reuptake }\end{array}$ & EMA, FDA & {$[36]$} \\
\hline $\begin{array}{l}\text { Bupropion/ } \\
\text { zonisamide }\end{array}$ & Empatic & 12 weeks & $\begin{array}{l}\text { Approx. } 7.2 \\
\mathrm{Kg}\end{array}$ & $\begin{array}{l}\text { Inhibits Noradrenaline/ dopamine } \\
\text { reuptake }\end{array}$ & FDA & {$[37]$} \\
\hline Topiramate & Topamax & 24 weeks & Approx. 6\% & $\begin{array}{l}\text { Physiologically blocks glutamate } \\
\text { receptors and carbonic anhydrase }\end{array}$ & FDA & {$[38]$} \\
\hline Phentermine & Adipex & 24 weeks & $\begin{array}{l}\text { Between } 7.2 \\
\text { to } 8.1 \%\end{array}$ & $\begin{array}{l}\text { Sympathomimetic amine and appetite } \\
\text { suppression }\end{array}$ & EMA, FDA & [39] \\
\hline $\begin{array}{l}\text { Phentermine/ } \\
\text { topiramate }\end{array}$ & Qsymia & 52 weeks & Approx 9\% & $\begin{array}{l}\text { Physiologically blocks glutamate } \\
\text { receptors and carbonic anhydrase and } \\
\text { catecholamine secretion }\end{array}$ & FDA & {$[40,41]$} \\
\hline Sibutramine & $\begin{array}{l}\text { Biomag, } \\
\text { Sibus, } \\
\text { Saciette }\end{array}$ & 52 weeks & $4 \mathrm{Kg}$ & $\begin{array}{l}\text { Block the reuptake of 5- } \\
\text { hydroxytryptamine and norepinephrine } \\
\text { serotonin, dopamine, }\end{array}$ & ANVISA & {$[42]$} \\
\hline Rimonabant & $\begin{array}{l}\text { Acomplia, } \\
\text { Redufast }\end{array}$ & 52 weeks & $4-7 \mathrm{Kg}$ & $\begin{array}{l}\text { Inverse agonist for the cannabinoid } \\
\text { receptor } \mathrm{CB} 1\end{array}$ & EMA & [43] \\
\hline Lorcaserin & Belviq & 52 weeks & $\begin{array}{l}\text { Approx. } \\
5.8 \%\end{array}$ & $\begin{array}{l}\text { Selective agonist for serotonin } 2 \mathrm{C} \\
\text { receptor }\end{array}$ & FDA & {$[44,45]$} \\
\hline Liraglutide & $\begin{array}{l}\text { Victoza, } \\
\text { Saxenda } \\
\end{array}$ & 52 weeks & $5 \%$ & Agonist for GLP-1 receptor & $\begin{array}{l}\text { EMA, FDA, } \\
\text { ANVISA }\end{array}$ & [46] \\
\hline Empagliflozin & Jardiance & 3 years & 1.5 to $2.0 \%$ & $\begin{array}{l}\text { Inhibits Sodium-glucose cotransporter } \\
2\end{array}$ & Phase I & [47] \\
\hline Cetilistat & Cetislim & 12 weeks & 3.3 to $4.1 \%$ & Pancreatic lipase inhibition & Japan & {$[48,49]$} \\
\hline Belonarib & $\begin{array}{l}\text { Not yet } \\
\text { given }\end{array}$ & 12 weeks & $\begin{array}{l}\text { Between 5- } \\
10 \mathrm{Kg}\end{array}$ & Methionine aminopeptidase 2 inhibition & $\begin{array}{l}\text { Phase II and } \\
\text { III }\end{array}$ & [50] \\
\hline
\end{tabular}

\section{Drugs used to treat obesity in the long term}

There are 5 different drugs or drug combination used in the long term to treat obesity. They are used as monotherapeutic or in combination therapy. Treatment of obesity is a long term process and involves medication, diet and physical exercise. Diet and physical exercise brings about a vast difference in the obese individual in the long term treatment.

Currently there are five drugs which are approved by the US FDA for the long term treatment of obesity. These medications should be taken in combination with physical exercise and proper diet. Orlistat, Lorcaserin, Liraglutide, Phentermine/ Topiramate and Naltrexone/ Bupropion are approved in the US and out of these, phentermine/ topiramate and lorcaserin are prohibited in Europe because of the safety issues [51, 52].

\section{Orlistat}

Orlistat was first approved in 1998 and it is the longest licensed drug to treat obesity. In United Kingdom and United States Orlistat sold as Alli by Figure 1: Orlistat GlaxoSmithKline and in most other countries as Xenical by Roche [53]. For the adults and adolescents of $\geq 12$ years of age orlistat-120mg prescribed 3 times a day before meals [54].

\section{Mechanism of action:}

Orlistat is highly potent and selective inhibitor of gastric and pancreatic lipase and thus inhibits the digestion of triglycerides into fatty acids. So, absorption of fatty acids becomes limited and undigested triglycerides excreted through feces. 
Absorption of Fatty acids decreases by at least $30 \%$ after taking Orlistat [55]. It has to be noted that people who take low lipid containing diet have less significance in taking Orlistat.

\section{Side effects}

Some of the major side effects include gastrointestinal symptoms like diarrhea, abdominal pain, oily stool, fecal urgency and flatulence [55]. Gastrointestinal issues can be resolved by co-prescribing a fiber containing supplement like psyllium or by increasing the fiber content in the diet.

\section{Efficacy}

Studies have been done for 4 years to comprehend the efficacy of the medication [56]. Ideal impacts have been found in association with diet and physical exercise brought about the decrease of $2.9 \mathrm{~kg}$ that is $95 \% \mathrm{CI}, 2.27-3.51 \mathrm{~kg}$ of the body weight when compared with placebo treatment. Critical loss in the weight of $5.8 \mathrm{~kg}$ versus $3.0 \mathrm{~kg}$; $\mathrm{p}<0.001$ when compared with placebo treatment in the diabetic prone obese patients [57$60]$.

\section{Lorcaserin}

Lorcaserin is a specific agonist of 5hydroxytryptamine (5-HT) 2C receptor found in the hypothalamus region of the brain, which is known

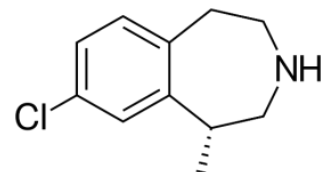

Figure 2 : Lorcaserin to control appetite. Lorcaserin was approved in 2012 for long term treatment of obesity, however in 2020 Lorcaserin was withdrawn from sale in USA because of the increased risk of cancer [61].

\section{Mechanism of action}

Activation of 5-HT2c receptors present in the hypothalamus of the brain leads to the stimulation of proopiomelanocortin (POMC), which in turn decreases the appetite by satiety. Lorcaserin is a selective 5-HT2C receptor agonist, upon binding to the receptor, reduces the feel of appetite, mood and also endocrine secretion. The appropriate mechanism of regulation of appetite is not yet fully understood [62, 63]. Lorcaserin has also found to interact with the $5-\mathrm{HT} 2_{\mathrm{C}}$ related receptors like $5-\mathrm{HT} 2_{\mathrm{B}}$ and $5-\mathrm{HT} 2_{\mathrm{A}}$ at a ratio of $100 \mathrm{x}$ and $17 \mathrm{x}$ times less than that of 5-HT2 ${ }_{C}$ receptor [64].

Side effects: Nausea, dizziness, fatigue, headache, dry mouth, constipation, back pain, cough and hypoglycemia are the few of the major side effects.

Efficacy:

A randomized, placebo treatment controlled, double blind investigation with more than 3000 individuals called BLOOM
(Behavioral Modification and Lorcaserin for Overweight and Obesity Management) clinical trial has been conducted to analyze the efficacy of lorcaserin $10 \mathrm{mg}$ twice day by day with placebo treatment. To summarize the trial, some of the patients who got lorcaserin in the first year asked to keep taking lorcaserin for the subsequent year and the rest of the patients were given the placebo treatment. $47.5 \%$ of patients who got Lorcaserin in the subsequent year lost more than $5 \%$ of their initial baseline body weight in year 1 and just $20.3 \%$ of the placebo treatment patients shed weight by over $5 \%(\mathrm{p}<0.001)$ $[65,66]$.

\section{Liraglutide}

Liraglutide is

an incretin

mimetic

agent which

is an agonist

for the

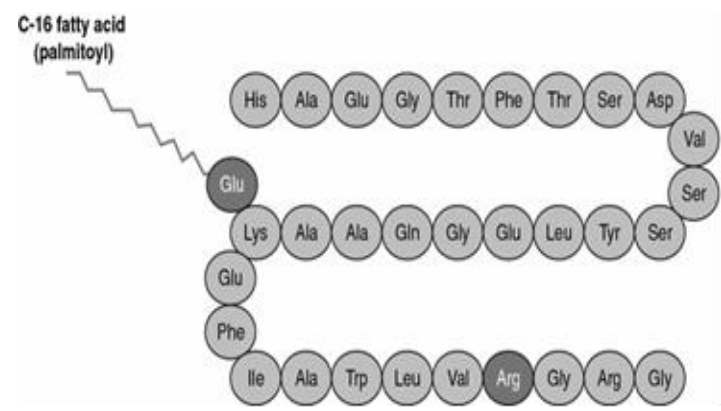

glucogon like peptide -1 receptor. This drug was approved by FDA in the year 2014 for Figure 3 Liraglutide subcutaneous injecton of $3 \mathrm{mg}$ per day [67].

\section{Mechanism of action}

Glucogon like peptide-1(GLP-1) binds to glucogon like peptide -1 receptor and enhances glucose dependent insulin secretion. GLP-1 has very less half-life of 1.5 to 2 minutes in the blood. Liraglutide is very stable in plasma and its half-life is found to be 13 hours [68]. The insulin produced will assist in managing blood glucose. GLP-1 is also known to induce postprandial satiety, slows down gastric emptying and decrease appetite [69].

\section{Side effects}

Some of the major side effects subtracted with placebo were nausea (25.0\%), diarrhea (11.6\%), vomiting (12.2\%), constipation (11.0\%), and dyspepsia (6.4\%) [70-72] Long term use of Liraglutide also leads to decrease in the level of HbA1c and blood pressure [73, 74].

Efficacy

A 8 month clinical trial of liraglutide in 564 obese-but-nondiabetic patients following the 5 month dose dependent placebo-controlled experiment of liraglutide in contrast with orlistat treatment (a normal weight reduction of $6.0 \mathrm{~kg}$ with liraglutide contrasted and orlistat $4.1 \mathrm{~kg}$ and with placebo 2.8 $\mathrm{kg}$ ) revealed that liraglutide at higher dose prompted 5.5 to 6.0 $\mathrm{kg}$ placebo-adjusted weight reduction in one year [75]. 


\section{Phentermine/topiramate}

It was the first combination drug approved by FDA in 2012 for the longer treatment of obesity. However it is not approved by EMA due to lack of long term studies related to cardiac related
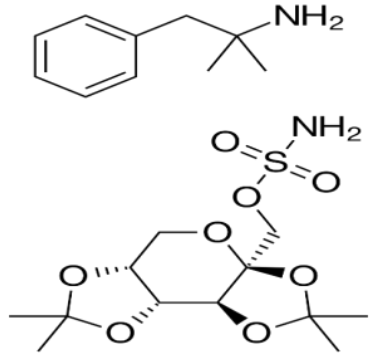
issues. Phentermine is a Figure 4: Phentermine/topiramate controlled drug substance since it comes under DEA schedule IV [76].

\section{Mechanism of action}

This combination drug works by suppressing the appetite in an unknown mechanism. Phentermine is a noradrenergic agonist and it enhances the release of norepinephrine, serotonin and dopamine by its sympathetic action [77]. Topiramate is a glutamate antagonist, $\gamma$-aminobutyric acid agonist and carbonic anhydrase inhibitor and was approved for treating epilepsy and migranes. But the epilepsy patients who received topiramate have significantly lost the weight and it paved the way to study topiramte for clinical trials to treat obesity. The action of topiramate have not been understood properly, however studies on rats suggest that topiramte is a neurostabilizer and enhances thermogenesis [78-80].

Side effects

Dizziness, paresthesia, dysgeusia, insomnia, dry mouth, tingling, constipation and sleeping trouble are few of the major side effects of the phentermine/ topiramate. Use of this drug is not recommended during pregnancy [81].

\section{Efficacy}

In clinical trials, individuals treated with the maximum dose of phentermine/topiramate along with a plan of diet and exercise lost $10 \%$ to $11 \%$ of their body weight contrasted with $1 \%$ to $2 \%$ for the individuals who got placebo. Moreover, $62 \%$ to $70 \%$ of subjects accepting the suggested dose or highest dose of phentermine/topiramate accomplished $\geq 5 \%$ weight decrease by week 56 (ITT-LOCF) compared with $17 \%$ to $21 \%$ of those getting a placebo [82].

\section{Naltrexone/ Bupropion}

Naltrexone/bupropion is a drug combination for long term treatment of obesity. This combination was approved by FDA in 2014. Individual drugs were used in 1980s for various health conditions. This is not controlled substance since it poses no potential abuse [76].

\section{Mechanism of action}

Synergistic effect of both Naltrexone and bupropion regulates the appetite and energy utilization. Naltrexone acts by inhibiting the reuptake of dopamine and norepinephrine and in turn it activates POMC in the hypothalamus. Naltrexone is opioid antagonist and it further increases the activity of Bupropion [83]. Side effects

Gastro-intestinal discomforts like
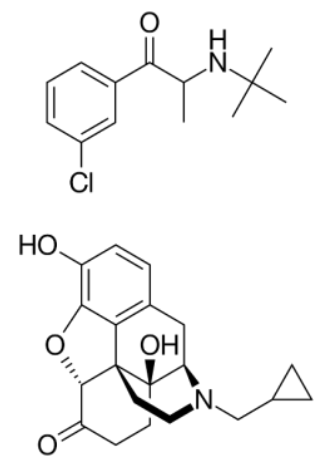

Figure 5: Naltrexone/ Bupropion nausea, vomiting, constipation, diarrhea and other side effects such as headache, dizziness and dry mouth. In long term use, patients with CVD may pose increased level of Blood pressure and heart rate [84].

Efficacy

In a clinical trial III, patients with no T2DM medicated with Naltrexone/Bupropion showed effective weight decrease of up to $9.3 \%$ from the baseline and patients with T2DM medicated with Naltrexone/Bupropion showed weight decrease of up to $5 \%$ and the data was submitted to FDA $[85,86]$. In 2015, Naltrexone/Bupropion affirmed by EMA following its treatment related to weight reduction in patients having $\mathrm{BMI}$ $\geq$ decrease the food admission and physical exercise in patients $\geq 30 \mathrm{Kg} / \mathrm{m} 2$ [87]

\section{New probable targets:}

Individual can continue taking these medications as long as they are benefiting from treatment and not having unpleasant side-effects. The increase of severe obesity in the patient population along with the co-morbidities, demands the development of novel drugs for treating obesity. This development is due to the proper understanding of the energy regulation and neuronal pathways which are involved in the energy homeostasis.

There are many new distinctive pathways have been studied which are involved in peripheral metabolic pathways. Many of the researchers are developing agonists for various pathways of peripheral metabolism like GLP-1R/Glucagon receptor twin agonists, triagonists for GLP-1 and GIP. One of the animal studies shows promising results in glycaemic management and weight reduction when injected with GLP-1/GIP/glucagon receptor triagonists [88]. Velneperit, one other drug which stops the binding of Neuropeptide Y to the Y5 receptor which reduces the hunger and thereby it manages energy balance. 
Velneperit showed high degree of positive response in clinical trials along with few side effects [50]. Cannabinoid receptor type 1 is one more achievable target [89]. Rimonabant is the antagonist and reverse agonist for $\mathrm{CB} 1$ receptor which reduced the weight rats in the animal studies $[90,91]$. It is found to be very effective for the people who have inflated medication tolerance [92]. However, in 2008 due to its psychiatric side effects like anxiety, depression and suicide ideation Rimonabant was withdrawn from US market. Taranabant, one more CB1 receptor antagonist and it also works same as Rimonabant also had same psychiatric issues. So, it is believed that, CB1 receptor antagonists are associated with major psychiatric issues and the antagonist which were at the developing stage were halted [93].

Discovery of a new kind of cells called beige fat cells which are a kind of adipose cells, help in enhancing the hormone sensitivity and also involved in antiobesity effects [94]. So the manipulation of these beige cells would result in loss of energy through thermogenesis and Physical activity [95, 96]. Further research on those cells should be done in order to get a complete picture of the fact on beige cells. Some evidences also reveal that inflammatory mediators like fat and macrophages have very important role in developing obesity induced hormone resistance [97-99]. Demonstrations by Lee et al. and Lumeng et al. also revealed that obesity induces inflammation by changing variety of inflammatory mediators like WBC, Neutrophils and also Ly6chi pro-inflammatory monocytes [100-101]. Salicylates and pioglitazone able to decrease the inflammation caused in animal models [102]. Some anti-obesity vaccines are also under development for including ghrelin, somatostatin and adenovirus36. Ghrelin is an orexigenic molecule secreted by stomach. Anti-ghrelin vaccine is shown to decrease food intake and increase energy expenditure [103]. Somatostatin is produced by hypothalamus, and is known to inhibit the secretion of growth hormone and insulin like growth factor-1. Somatostatin vaccination increases the GH and IGF-1 and decreases obesity [104]. Adenovirus36 (ad36) known to increase the risk of obesity by causing inflammation and adiposity [105].

\section{CONCLUSION}

Treating obesity is still one of the complicated challenges till today. As this review encompasses, even though the cases of obesity increasing, there are drugs which can work at various pathways and mechanisms which can manage hunger, satiety and appetite. By keeping the target to progress in finding the better medication for obesity, existing drugs and new targets have to be understood properly. With the development of new therapeutics, anti-obesity drugs have a potential to largely expand and allow better as well as personalized treatment options. Further, studies should be carried out to prove the ability of the drug to reach to its target site in the body and the ability of the drug to adapt into environment and the lifestyle of the individual. Switching to healthy diet and adequate physical exercise as well as proper medication may be the better road to success.

\section{FINANCIAL ASSISTANCE \\ Nil}

\section{CONFLICT OF INTEREST}

The authors declare no conflict of interest

\section{REFERENCES}

[1] Mohamed GA, Ibrahim SRM, Elkhayat ES, El Dine RS. Natural anti-obesity agents. Bull. Fac. Pharmacy, Cairo Univ., 52, 269-84 (2014).

[2] Oh S, Kim K, Chung Y, Shong M, Park S. Anti-obesity Agents: A Focused Review on the Structural Classification of Therapeutic Entities. Curr. Top. Med. Chem., 9, 466-81 (2009).

[3] Hatware KV, Sharma S, Patil K, Shete M, Karri S, Gupta G. Evidence for gastroprotective, anti-inflammatory and antioxidant potential of methanolic extract of Cordia dichotoma leaves on indomethacin and stress induced gastric lesions in Wistar rats. Biomed. Pharmacother., 103, 317-25 (2018).

[4] World health organization. "Obesity and overweight." : <https://www.who.int/news-room/factsheets/detail/obesity-and-overweight, cited 01 April, 2020.

[5] World Rankings. "Obesity Rates by Country (July 2017)." : $\quad$ https://renewbariatrics.com/obesity-rank-by-countries/ cited 01 April, 2020

[6] Redinger RN (2007). The pathophysiology of obesity and its clinical manifestations. Gastroenterology \& hepatology, 3(11), 856.

[7] Food and Drug Administration. "Orlistat nonprescription briefing document: NDA 21- 887. Endocrine and metabolic drugs advisory committee meeting, January 23, 2006.": 
<http://www.fda.gov/ohrms/dockets/ac/06/briefing/20064201B1_02 03-FDA-Clinical-Review.Pdf. cited on 21 January, 2020

[8] Xia Y, Kelton CML, Guo JJ, Bian B, Heaton PC. Treatment of obesity: Pharmacotherapy trends in the United States from 1999 to 2010. Obesity, 23, 1721-8 (2015).

[9] Sternson SM, Eiselt A-K. Three Pillars for the Neural Control of Appetite. Annu. Rev. Physiol., 79, 401-23 (2017).

[10] Muppala S, Konduru SKP, Merchant N, Ramsoondar J, Rampersad CK, Rajitha B, Mukund V, Kancherla J, Hammond A, Barik TK, Mannarapu M, Alam A, Basha R, Bramhachari PV, Verma D, Sushma PS, Pattnaik S, Nagaraju GP. Adiponectin: Its role in obesity-associated colon and prostate cancers. Crit. Rev. Oncol. Hematol., 116, 125-33 (2017).

[11] Nagaraju GP, Aliya S, Alese OB. Role of adiponectin in obesity related gastrointestinal carcinogenesis. Cytokine Growth Factor Rev., 26, 83-93 (2015).

[12] Rodgers RJ, Tschop MH, Wilding JPH. Anti-obesity drugs: past, present and future. Dis. Model. Mech., 5, 6216 (2012).

[13]Zhang Y, Liu J, Yao J, Ji G, Qian L, Wang J, Zhang G, Tian J, Nie Y, Zhang Y, Gold M, Liu Y. Obesity: Pathophysiology and Intervention. Nutrients, 6, 5153-83 (2014).

[14] Han L-K, Xu B-J, Kimura Y, Zheng Y, Okuda H. Platycodi Radix Affects Lipid Metabolism in Mice with High Fat Diet-Induced Obesity. J. Nutr., 130, 2760-4 (2000).

[15] Asai A, Miyazawa T. Dietary Curcuminoids Prevent HighFat Diet-Induced Lipid Accumulation in Rat Liver and Epididymal Adipose Tissue. J. Nutr., 131, 2932-5 (2001).

[16] Ohia SE, Opere CA, LeDay AM, Bagchi M, Bagchi D, Stohs SJ. Safety and mechanism of appetite suppression by a novel hydroxycitric acid extract (HCA-SX). Mol. Cell. Biochem., 238, 89-103 (2002).

[17] Shin J-E, Han MJ, Kim D-H. 3-Methylethergalangin Isolated from Alpinia officinarum Inhibits Pancreatic Lipase. Biol. Pharm. Bull., 26, 854-7 (2003).

[18] KWON C-S, SOHN HY, KIM SH, KIM JH, SON KH, LEE JS, LIM JK, KIM J-S. Anti-obesity Effect of Dioscorea nipponica Makino with Lipase-inhibitory
Activity in Rodents. Biosci. Biotechnol. Biochem., 67, 1451-6 (2003).

[19] Han L-K, Sumiyoshi M, Zheng Y-N, Okuda H, Kimura Y. Anti-obesity action ofSalix matsudana leaves (Part 2). Isolation of anti-obesity effectors from polyphenol fractions ofSalix matsudana. Phyther. Res., 17, 1195-8 (2003).

[20]Zhao HL, Kim YS. Determination of the kinetic properties of platycodin $\mathrm{D}$ for the inhibition of pancreatic lipase using a 1,2-diglyceride-based colorimetric assay. Arch. Pharm. Res., 27, 1048-52 (2004).

[21] Cha Y-S, Rhee S-J, Heo Y-R. Acanthopanax senticosus Extract Prepared from Cultured Cells Decreases Adiposity and Obesity Indices in C57BL/6J Mice Fed a High Fat Diet. J. Med. Food, 7, 422-9 (2004).

[22] Shin J-E, Han MJ, Song M-C, Baek N-I, Kim D-H. 5Hydroxy-7-(4'-hydroxy-3'-methoxyphenyl)-1-phenyl-3-

heptanone: A Pancreatic Lipase Inhibitor Isolated from Alpinia officinarum. Biol. Pharm. Bull., 27, 138-40 (2004).

[23] Ninomiya K, Matsuda H, Shimoda H, Nishida N, Kasajima N, Yoshino T, Morikawa T, Yoshikawa M. Carnosic acid, a new class of lipid absorption inhibitor from sage. Bioorg. Med. Chem. Lett., 14, 1943-6 (2004).

[24] Kumar A, Vimalavathini R. Possible anorectic effect of methanol extract of Benincasa hispida (Thunb). Cogn, fruit. Indian J Pharmacol., 36, 348-50 (2004)

[25] Lee I-A, Lee JH, Baek N-I, Kim D-H. Antihyperlipidemic Effect of Crocin Isolated from the Fructus of Gardenia jasminoides and Its Metabolite Crocetin. Biol. Pharm. Bull., 28, 2106-10 (2005).

[26] Han L-K, Zheng Y-N, Yoshikawa M, Okuda H, Kimura Y. Anti-obesity effects of chikusetsusaponins isolated from Panax japonicus rhizomes. BMC Complement. Altern. Med., 5, 9 (2005).

[27]Leibel RL, Seeley RJ, Darsow T, Berg EG, Smith SR, Ratner R. Biologic Responses to Weight Loss and Weight Regain: Report From an American Diabetes Association Research Symposium. Diabetes, 64, 2299-309 (2015).

[28] Ochner CN, Tsai AG, Kushner RF, Wadden TA. Treating obesity seriously: when recommendations for lifestyle change confront biological adaptations. Lancet Diabetes Endocrinol., 3, 232-4 (2015).

[29] Garvey WT, Mechanick JI, Brett EM, Garber AJ, Hurley DL, Jastreboff AM, Nadolsky K, Pessah-Pollack R, 
Plodkowski R. American Association of Clinical Endocrinologists and American College of Endocrinology Comprehensive clinical practice guidelines for medical care of patients with obesity. Endocr. Pract., 22, 1-203 (2016).

[30] Apovian CM, Aronne L, Rubino D, Still C, Wyatt H, Burns C, Kim D, Dunayevich E. A randomized, phase 3 trial of naltrexone SR/bupropion SR on weight and obesity-related risk factors (COR-II). Obesity, 21, 935-43 (2013).

[31] Wadden TA, Butryn ML, Hong PS, Tsai AG. Behavioral Treatment of Obesity in Patients Encountered in Primary Care Settings. JAMA, 312, 1779 (2014).

[32] Finucane MM, Stevens GA, Cowan MJ, Danaei G, Lin JK, Paciorek CJ, Singh GM, Gutierrez HR, Lu Y, Bahalim AN, Farzadfar F, Riley LM, Ezzati M. National, regional, and global trends in body-mass index since 1980: systematic analysis of health examination surveys and epidemiological studies with 960 country-years and 9.1 million participants. Lancet, 377, 557-67 (2011).

[33] Padwal R, Li SK, Lau DCW. Long-term pharmacotherapy for overweight and obesity: a systematic review and metaanalysis of randomized controlled trials. Int. J. Obes., 27, 1437-46 (2003).

[34] Rucker D, Padwal R, Li SK, Curioni C, Lau DCW. Long term pharmacotherapy for obesity and overweight: updated meta-analysis. BMJ, 335, 1194-9 (2007).

[35] Gadde KM, Parker CB, Maner LG, Wagner HR, Logue EJ, Drezner MK, Krishnan KRR. Bupropion for Weight Loss: An Investigation of Efficacy and Tolerability in Overweight and Obese Women. Obes. Res., 9, 544-51 (2001).

[36] United States Food and Drug administration (2010). "FDA reduction Document: NDA 200063: Contrave (Naltrexone $4 \mathrm{mg}, 8 \mathrm{mg} /$ Bupropion HCL $90 \mathrm{mg}$ Extended Release Tablet)"

https://www.accessdata.fda.gov/drugsatfda_docs/nda/2014 1200063Orig1s000ClinPharmR.pdf, Cited on 20 december, 2019.

[37] Gadde KM, Yonish GM, Foust MS, Wagner HR. Combination Therapy of Zonisamide and Bupropion for Weight Reduction in Obese Women. J. Clin. Psychiatry, 68, 1226-9 (2007).

[38] Li Z, Maglione M, Tu W, Mojica W, Arterburn D, Shugarman LR, Hilton L, Suttorp M, Solomon V, Shekelle
PG, Morton SC. Meta-Analysis: Pharmacologic Treatment of Obesity. Ann. Intern. Med., 142, 532 (2005).

[39] Haddock C, Poston W, Dill P, Foreyt J, Ericsson M. Pharmacotherapy for obesity: a quantitative analysis of four decades of published randomized clinical trials. Int. J. Obes., 26, 262-73 (2002).

[40] Gadde KM, Allison DB, Ryan DH, Peterson CA, Troupin B, Schwiers ML, Day WW. Effects of low-dose, controlled-release, phentermine plus topiramate combination on weight and associated comorbidities in overweight and obese adults (CONQUER): a randomised, placebo-controlled, phase 3 trial. Lancet, 377, 1341-52 (2011).

[41] Allison DB, Gadde KM, Garvey WT, Peterson CA, Schwiers ML, Najarian T, Tam PY, Troupin B, Day WW. Controlled-Release Phentermine/Topiramate in Severely Obese Adults: A Randomized Controlled Trial (EQUIP). Obesity, 20, 330-42 (2012).

[42] Padwal R, Li S, Lau D. Long-term pharmacotherapy for obesity and overweight. The Cochrane Database of Systematic Reviews (Protocol). John Wiley \& Sons, Ltd, Chichester, UK, (2002).

[43] Christensen R, Kristensen PK, Bartels EM, Bliddal H, Astrup A. Efficacy and safety of the weight-loss drug rimonabant: a meta-analysis of randomised trials. Lancet, 370, 1706-13 (2007).

[44] O’Neil PM, Smith SR, Weissman NJ, Fidler MC, Sanchez M, Zhang J, Raether B, Anderson CM, Shanahan WR. Randomized Placebo-Controlled Clinical Trial of Lorcaserin for Weight Loss in Type 2 Diabetes Mellitus: The BLOOM-DM Study. Obesity, 20, 1426-36 (2012).

[45]Fidler MC, Sanchez M, Raether B, Weissman NJ, Smith SR, Shanahan WR, Anderson CM. A One-Year Randomized Trial of Lorcaserin for Weight Loss in Obese and Overweight Adults: The BLOSSOM Trial. J. Clin. Endocrinol. Metab., 96, 3067-77 (2011).

[46]Pi-Sunyer X, Astrup A, Fujioka K, Greenway F, Halpern A, Krempf M, Lau DCW, le Roux CW, Violante Ortiz R, Jensen CB, Wilding JPH. A Randomized, Controlled Trial of $3.0 \mathrm{mg}$ of Liraglutide in Weight Management. N. Engl. J. Med., 373, 11-22 (2015).

[47]Zinman B, Wanner C, Lachin JM, Fitchett D, Bluhmki E, Hantel S, Mattheus M, Devins T, Johansen OE, Woerle HJ, Broedl UC, Inzucchi SE. Empagliflozin, 
Cardiovascular Outcomes, and Mortality in Type 2

Diabetes. N. Engl. J. Med., 373, 2117-28 (2015).

[48] Kopelman P, Bryson A, Hickling R, Rissanen A, Rossner

S, Toubro S, Valensi P. Cetilistat (ATL-962), a novel lipase inhibitor: a 12-week randomized, placebo-controlled study of weight reduction in obese patients. Int. J. Obes., 31, 494-9 (2007).

[49] Kopelman P, de Groot HG, Rissanen A, Rossner S, Toubro S, Palmer R, Hallam R, Bryson A, Hickling RI. Weight Loss, HbA 1c Reduction, and Tolerability of Cetilistat in a Randomized, Placebo-controlled Phase 2 Trial in Obese Diabetics: Comparison With Orlistat (Xenical). Obesity, 18, 108-15 (2010).

[50] Kim DD, Krishnarajah J, Lillioja S, de Looze F, Marjason J, Proietto J, Shakib S, Stuckey BGA, Vath JE, Hughes TE. Efficacy and safety of beloranib for weight loss in obese adults: a randomized controlled trial. Diabetes, Obes. Metab., 17, 566-72 (2015).

[51]Londono Lemos ME. Pharmacological Advances to the Treatment of Obesity. J. Child. Obes., 03, (2018).

[52] Siebenhofer A, Jeitler K, Horvath K, Berghold A, Posch N, Meschik J, Semlitsch T. Long-term effects of weightreducing drugs in people with hypertension. Cochrane Database Syst. Rev., (2016).

[53]Zhi J, Melia AT, Eggers H, Joly R, Patel IH. Review of Limited Systemic Absorption of Orlistat, a Lipase Inhibitor, in Healthy Human Volunteers. J. Clin. Pharmacol., 35, 1103-8 (1995).

[54]Xenical information. "Xenical (orlistat) patient information. South SanFrancisco (CA). Genentech USA, Inc.; c2016" :

[55]<https://www.aace.com/files/obesity/toolkit/ xenical_patient_info.pdf. cited 01 January 2020

[56] Yanovski SZ, Yanovski JA. Long-term Drug Treatment for Obesity. JAMA, 311, 74 (2014).

[57] Bray GA, Ryan DH. Medical Therapy for the Patient With Obesity. Circulation, 125, 1695-703 (2012).

[58] Li Z, Maglione M, Tu W, Mojica W, Arterburn D, Shugarman LR, Hilton L, Suttorp M, Solomon V, Shekelle PG, Morton SC. Meta-Analysis: Pharmacologic Treatment of Obesity. Ann. Intern. Med., 142, 532 (2005).

[59] Padwal R, Li SK, Lau DCW. Long-term pharmacotherapy for overweight and obesity: a systematic review and metaanalysis of randomized controlled trials. Int. J. Obes., 27, 1437-46 (2003).
[60] Torgerson JS, Hauptman J, Boldrin MN, Sjostrom L. XENical in the Prevention of Diabetes in Obese Subjects (XENDOS) Study: A randomized study of orlistat as an adjunct to lifestyle changes for the prevention of type 2 diabetes in obese patients. Diabetes Care, 27, 155-61 (2004).

[61] Scheen AJ, Ernest P. New antiobesity agents in type 2 diabetes: overview of clinical trials with sibutramine and orlistat. Diabetes Metab., 28, 437-45 (2002).

[62] The US Food and Drug Administration. "FDA drug safety communication. Silver Spring (MD): Belviq, The US Food and Drug Administration; c2020" <https://www.fda.gov/drugs/drug-safety-andavailability/fda-requests-withdrawal-weight-loss-drugbelviq-belviq-xr-lorcaserin-market cited on 16 February, 2020

[63] Spreitzer H, "Lorcaserin". Österreichische Apothekerzeitung (in German), 19, 1083-64 (2010).

[64] Millan MJ. Serotonin 5-HT2C Receptors as a Target for the Treatment of Depressive and Anxious States: Focus on Novel Therapeutic Strategies. Therapies, 60, 441-60 (2005).

[65] Smith BM, Smith JM, Tsai JH, Schultz JA, Gilson CA, Estrada SA, Chen RR, Park DM, Prieto EB, Gallardo CS, Sengupta D, Thomsen WJ, Saldana HR, Whelan KT, Menzaghi F, Webb RR, Beeley NRA. Discovery and SAR of new benzazepines as potent and selective 5-HT2C receptor agonists for the treatment of obesity. Bioorg. Med. Chem. Lett., 15, 1467-70 (2005).

[66] O’Neil PM, Smith SR, Weissman NJ, Fidler MC, Sanchez M, Zhang J, Raether B, Anderson CM, Shanahan WR. Randomized Placebo-Controlled Clinical Trial of Lorcaserin for Weight Loss in Type 2 Diabetes Mellitus: The BLOOM-DM Study. Obesity, 20, 1426-36 (2012).

[67]Fidler MC, Sanchez M, Raether B, Weissman NJ, Smith SR, Shanahan WR, Anderson CM. A One-Year Randomized Trial of Lorcaserin for Weight Loss in Obese and Overweight Adults: The BLOSSOM Trial. J. Clin. Endocrinol. Metab., 96, 3067-77 (2011).

[68] Upadhyay J, Polyzos SA, Perakakis N, Thakkar B, Paschou SA, Katsiki N, Underwood P, Park K-H, Seufert J, Kang ES, Sternthal E, Karagiannis A, Mantzoros CS. Pharmacotherapy of type 2 diabetes: An update. Metabolism, 78, 13-42 (2018). 
[69] Farr OM, Tsoukas MA, Triantafyllou G, Dincer F, Filippaios A, Ko B-J, Mantzoros CS. Short-term administration of the GLP-1 analog liraglutide decreases circulating leptin and increases GIP levels and these changes are associated with alterations in CNS responses to food cues: A randomized, placebo-controlled, crossover study. Metabolism, 65, 945-53 (2016).

[70] Kulve JS, Veltman DJ, van Bloemendaal L, Barkhof F, Drent ML, Diamant M, IJzerman RG. Liraglutide Reduces CNS Activation in Response to Visual Food Cues Only After Short-term Treatment in Patients With Type 2 Diabetes. Diabetes Care, dc150772 (2015).

[71]Lean MEJ, Carraro R, Finer N, Hartvig H, Lindegaard ML, Rössner S, Van Gaal L, Astrup A. Tolerability of nausea and vomiting and associations with weight loss in a randomized trial of liraglutide in obese, non-diabetic adults. Int. J. Obes., 38, 689-97 (2014).

[72] Pi-Sunyer X, Astrup A, Fujioka K, Greenway F, Halpern A, Krempf M, Lau DCW, le Roux CW, Violante Ortiz R, Jensen CB, Wilding JPH. A Randomized, Controlled Trial of $3.0 \mathrm{mg}$ of Liraglutide in Weight Management. N. Engl. J. Med., 373, 11-22 (2015).

[73] Farr OM, Sofopoulos M, Tsoukas MA, Dincer F, Thakkar B, Sahin-Efe A, Filippaios A, Bowers J, Srnka A, Gavrieli A, Ko B-J, Liakou C, Kanyuch N, Tseleni-Balafouta S, Mantzoros CS. GLP-1 receptors exist in the parietal cortex, hypothalamus and medulla of human brains and the GLP-1 analogue liraglutide alters brain activity related to highly desirable food cues in individuals with diabetes: a crossover, randomised, placebo-controlled. Diabetologia, 59, 954-65 (2016).

[74] Blonde L, Klein EJ, Han J, Zhang B, Mac SM, Poon TH, Taylor KL, Trautmann ME, Kim DD, Kendall DM. Interim analysis of the effects of exenatide treatment on A1C, weight and cardiovascular risk factors over 82 weeks in 314 overweight patients with type 2 diabetes. Diabetes, Obes. Metab., 8, 436-47 (2006).

[75] Nauck M, Frid A, Hermansen K, Shah NS, Tankova T, Mitha IH, Zdravkovic M, During M, Matthews DR. Efficacy and Safety Comparison of Liraglutide, Glimepiride, and Placebo, All in Combination With Metformin, in Type 2 Diabetes: The LEAD (Liraglutide Effect and Action in Diabetes)-2 study. Diabetes Care, 32, 84-90 (2009).
[76] Astrup A, Rössner S, Van Gaal L, Rissanen A, Niskanen L, Al Hakim M, Madsen J, Rasmussen MF, Lean ME. Effects of liraglutide in the treatment of obesity: a randomised, double-blind, placebo-controlled study. Lancet, 374, 1606-16 (2009).

[77] Tak YJ, Lee SY. Anti-Obesity Drugs: Long-Term Efficacy and Safety: An Updated Review. World J. Mens. Health, 38, (2020).

[78] Rothman RB, Baumann MH. Appetite Suppressants, Cardiac Valve Disease and Combination Pharmacotherapy. Am. J. Ther., 16, 354-64 (2009).

[79] Velazquez A, Apovian CM. Updates on obesity pharmacotherapy. Ann. N. Y. Acad. Sci., 1411, 106-19 (2018).

[80]Picard F, Deshaies Y, Lalonde J, Samson P, Richard D. Topiramate Reduces Energy and Fat Gains in Lean ( $\mathrm{Fa} /$ ? ) and Obese ( fa/fa ) Zucker Rats. Obes. Res., 8, 656-63 (2000).

[81]Richard D, Picard F, Lemieux C, Lalonde J, Samson P, Deshaies Y. The effects of topiramate and sex hormones on energy balance of male and female rats. Int. J. Obes., 26, 344-53 (2002).

[82]Jordan J, Astrup A, Engeli S, Narkiewicz K, Day WW, Finer N. Cardiovascular effects of phentermine and topiramate. J. Hypertens., 32, 1178-88 (2014).

[83] Information on qsymia. "qsymia full prescribing information"

<https://qsymia.com/patient/include/media/pdf/prescribing -information.pdf, cited on 01 April, 2020.

[84] Greenway FL, Whitehouse MJ, Guttadauria M, Anderson JW, Atkinson RL, Fujioka K, Gadde KM, Gupta AK, O’Neil P, Schumacher D, Smith D, Dunayevich E, Tollefson GD, Weber E, Cowley MA. Rational Design of a Combination Medication for the Treatment of Obesity. Obesity, 17, 30-9 (2009).

[85] Apovian CM, Aronne LJ, Bessesen DH, McDonnell ME, Murad MH, Pagotto U, Ryan DH, Still CD. Pharmacological Management of Obesity: An Endocrine Society Clinical Practice Guideline. J. Clin. Endocrinol. Metab., 100, 342-62 (2015).

[86] United States Food and Drug Administration (2010). "FDA Briefing Document: NDA 200063: Contrave (Naltrexone $4 \mathrm{mg}, 8 \mathrm{mg} /$ Bupropion HCL $90 \mathrm{mg}$ Extended Release Tablet)" 
https://www.accessdata.fda.gov/drugsatfda_docs/nda/2014 /200063Orig1s000MedR.pdf, Cited on 01 April, 2020.

[87] United States Food and Drug Administration (2014). "Center for Drug Evaluation and Research. NDA 200063 Orig1s000" $<$ https://www.accessdata.fda.gov/drugsatfda_docs/nda/201 4/200063Orig1s000SumR.pdf, Cited on 02 April, 2020.

[88] European Medicines Agency. "Mysimba Summary of Product Characteristics"

$<$ https://www.ema.europa.eu/en/medicines/human/EPAR/ mysimba, Cited on 02 April, 2020.

[89] George M, Rajaram M, Shanmugam E. New and Emerging Drug Molecules Against Obesity. J. Cardiovasc. Pharmacol. Ther., 19, 65-76 (2014).

[90]Finan B, Yang B, Ottaway N, Smiley DL, Ma T, Clemmensen C, Chabenne J, Zhang L, Habegger KM, Fischer K, Campbell JE, Sandoval D, Seeley RJ, Bleicher K, Uhles S, Riboulet W, Funk J, Hertel C, Belli S, Sebokova E, Conde-Knape K, Konkar A, Drucker DJ, Gelfanov V, Pfluger PT, Müller TD, Perez-Tilve D, DiMarchi RD, Tschöp MH. A rationally designed monomeric peptide triagonist corrects obesity and diabetes in rodents. Nat. Med., 21, 27-36 (2015).

[91]Rodgers RJ, Tschop MH, Wilding JPH. Anti-obesity drugs: past, present and future. Dis. Model. Mech., 5, 6216 (2012).

[92] Pertwee RG. The pharmacology of cannabinoid receptors and their ligands: an overview. Int. J. Obes., 30, S13-8 (2006).

[93] Cluny NL, Chambers AP, Vemuri VK, Wood JT, Eller LK, Freni C, Reimer RA, Makriyannis A, Sharkey KA. The neutral cannabinoid CB1 receptor antagonist AM4113 regulates body weight through changes in energy intake in the rat. Pharmacol. Biochem. Behav., 97, 537-43 (2011).

[94] Kang JG, Park C-Y. Anti-Obesity Drugs: A Review about Their Effects and Safety. Diabetes Metab. J., 36, 13 (2012).

[95] Randall PA, Vemuri VK, Segovia KN, Torres EF, Hosmer S, Nunes EJ, Santerre JL, Makriyannis A, Salamone JD. The novel cannabinoid CB1 antagonist AM6545 suppresses food intake and food-reinforced behavior. Pharmacol. Biochem. Behav., 97, 179-84 (2010).

[96] Harms M, Seale P. Brown and beige fat: development, function and therapeutic potential. Nat. Med., 19, 1252-63 (2013).
[97]Wang QA, Tao C, Gupta RK, Scherer PE. Tracking adipogenesis during white adipose tissue development, expansion and regeneration. Nat. Med., 19, 1338-44 (2013).

[98] Boström P, Wu J, Jedrychowski MP, Korde A, Ye L, Lo JC, Rasbach KA, Boström EA, Choi JH, Long JZ, Kajimura S, Zingaretti MC, Vind BF, Tu H, Cinti S, Højlund K, Gygi SP, Spiegelman BM. A PGC1- $\alpha$ dependent myokine that drives brown-fat-like development of white fat and thermogenesis. Nature, 481, 463-8 (2012).

[99]Romeo GR, Lee J, Shoelson SE. Metabolic Syndrome, Insulin Resistance, and Roles of Inflammation Mechanisms and Therapeutic Targets. Arterioscler. Thromb. Vasc. Biol., 32, 1771-6 (2012).

[100] Osborn O, Olefsky JM. The cellular and signaling networks linking the immune system and metabolism in disease. Nat. Med., 18, 363-74 (2012).

[101] Lee B-C, Lee J. Cellular and molecular players in adipose tissue inflammation in the development of obesityinduced insulin resistance. Biochim. Biophys. Acta - Mol. Basis Dis., 1842, 446-62 (2014).

[102] Lumeng CN, DeYoung SM, Bodzin JL, Saltiel AR. Increased Inflammatory Properties of Adipose Tissue Macrophages Recruited During Diet-Induced Obesity. Diabetes, 56, 16-23 (2007).

[103] Kim M-S, Yamamoto Y, Kim K, Kamei N, Shimada T, Liu L, Moore K, Woo JR, Shoelson SE, Lee J. Regulation of Diet-Induced Adipose Tissue and Systemic Inflammation by Salicylates and Pioglitazone. PLoS One, 8, e82847 (2013).

[104] Rotkvic V, Altabas V. Anti-ghrelin antibodies in appetite suppression: recent advances in obesity pharmacotherapy. ImmunoTargets Ther., 123 (2015).

[105] Monteiro MP. Obesity vaccines. Hum. Vaccin. Immunother., 10, 887-95 (2014).

[106] Yamada T, Hara K, Kadowaki T. Association of Adenovirus 36 Infection with Obesity and Metabolic Markers in Humans: A Meta-Analysis of Observational Studies. PLoS One, 7, e42031 (2012). 